\title{
Assessment and Students Alignment: The Case of a Portuguese Business Simulation Course
}

\author{
Helena Costa Oliveira ${ }^{*}$, Luís Gomes ${ }^{1}$ \\ ${ }^{1}$ Polytechnic of Porto, 4200-465, Porto, Portugal
}

\begin{abstract}
In high education, assessment components are very important as condition the student's success. Such components must involve several issues including soft and hard skills. The quality of education will depend on the alignment of such skill and their assimilation by students. We present a course taught in Portuguese, belonging to the graduation of Accounting and Administration, that covers several assessment tasks such as oral presentation, written exams, operationalization of tasks, assessment of physical dossiers, punctuality and attendance, ethical behaviour, and company management report. Data were collected in 2019 thought to triangulate methods, namely documental analyses, direct observation, and paper questionnaires. We aim to evaluate the degree of importance perceived by students for each evaluation component. We conclude that the students consider all of the components very important, attributing less importance to hard skills, namely the multidisciplinary contents evaluated thought written exams. This paper contributes to higher education studies by presenting the alignment of an assessment model and students.
\end{abstract}

\section{Introduction}

Higher education is constantly changing as digital impacts the teacher-student relationship. Teaching process deals with a vast content of digital information that requires the adaptation of the curriculum. Multidisciplinary and digital content integration is required in 4.0 education.

The complexity of the digital business world changes the role of the accountant. Accounting education had to adapt to prepare students for an increasingly complex and uncertain world. The new accountant professional has to be hard skills and above all soft skills. Increasingly skills such as ethics, objectivity, written ability, creativity, oral communication, teamwork are more required. This makes the evaluation and assessment process complex and time-consuming.

We present the assessment and evaluation model of a digitization course of high accounting education. The Business Simulation Project (BSP) course is supported by information technology and incorporates new skills in the student's curriculum. This course is based on management simulation which stimulates reflection as a fundamental skill for potentiating the learning process ${ }^{1}$. Our purpose is to characterize the BSP course, analyse its assessment model and the importance assigned to each assessment component by students.

\footnotetext{
* Corresponding author: helena@iscap.ipp.pt
} 
The study of digitalization in higher education institutions is most evident in social sciences, where accounting is included ${ }^{2}$, and our aim is to contribute to such scientific development.

The paper is structured as follows. The next section presents the literature review, followed by methodology. In the findings and discussion section, we present the assessment model and the student's perception of assessment components. In the last section, we present the conclusions.

\section{Literature Review}

There are many stereotypes about accounting professional, to contradict its negative perception new models of learning account have emerged ${ }^{3}$. The contemporary accounting education incorporates business simulation models. These models involve an expository phase by the teachers, the participation of students in the simulation, the feedback by the teachers and the necessary correction by the students ${ }^{4}$. They are eminently practical, aiming to prepare students for the higher competition and uncertainty of current organizations. New forms of organizations have been emerged such as virtual organizations, based on information technology and seeking new skills such as personal, social and technological.

One issue that affects the future career of students is the assessment. It focuses the students on the essential and relevant for their success. The assessment has a greater impact on student learning than teaching itself. It is a set of components that measure the outcome of student's learning, in terms of knowledge acquired, development and skills increased. It decided if students are able to pass to the next educational level and in the end to step into the labour market ${ }^{5}$. The main aspect of assessment is the feedback provided. Thought the comparing of educational performance with educational purposes and expectations it allows students to improve and learn ${ }^{6}$.

There are a multiplicity of assessment instruments in order to overcome higher education disability ${ }^{7}$. Multiple assessment components have been incorporated to better prepare students for the organizational context but also in order to motivate and engages students interests ${ }^{8}$. The assessment process can also incorporate several components over the semester to reveal change, growth, and degrees of integration ${ }^{6}$.

Accounting education incorporates increasingly multiple assessment components improving new skills. The evaluation assessment impacts the quality of education and the perception of students to assessment in accounting education. The student's preferred assessment tasks are not homogeneous and may vary according to cultural aptitudes ${ }^{9}$.

Several assessment competencies have been considered in accounting curricula such as the oral communication and presentation skills, enabling cognitive thinking to students ${ }^{10}$ and help to develop nonaccounting skills indispensable for students professional success ${ }^{6}$. Ethical and objectivity issues have been increasingly significant in accounting education ${ }^{11}$. Despite the evaluation of skills and abilities, another component is the exam focus on the knowledge ${ }^{6}$. Personal skills such as assiduity and above all punctuality are increasingly important and difficult to internalize in Portuguese culture.

This kind of assessment model, incorporating several components, can be a burden for teachers ${ }^{5}$ however it is comforting when the future of good workers have been prepared.

\section{Methodology}

We study a Portuguese course of BSP in the graduation of Accounting Administration in the School of Accounting and Administration belonging to the Polytechnic of Porto. The course is divided into two: BSP I and BSP II. It is a multidisciplinary course and is taught in the last year of graduation. The students are organized in groups where teamwork is foster. They 
have to manage a virtual company, throughout the school year, with the same legal and organizational requirements of real-life companies. The group has between two and four students. This course has precedence; it is only possible to attend BSP II after concluding successfully BSP I.

We study the course in 2019, in the second semester after the conclusion of the first one. This allows better assimilation and understanding of the operationalization and of the assessment components from the student. The BSP has 258 students.

We present a triangulation method of research. We use quantitative survey research ${ }^{12}$ and a qualitative analyse ${ }^{13}$. The purpose of the paper is to describe the assessment and evaluation models of BSP particularly its components and to perceive the degree of importance assigned to each evaluation component by the students. For the first aim, we rely on qualitative research methods and use documental analyses and direct observation ${ }^{14}$.

According to the second purpose, we rely on quantitative research and formulate two hypotheses.

\section{H1: The student's perception of the several evaluation components differs according to professional experience.}

Potential employers of accountants including persons with recruiting experience and young executives consider component skills such as communication and practical training important ${ }^{11}$. Students with no professional experience may have a different perception of the importance of some components.

\section{H2: The students' perception of the various evaluation components differs according to the first-semester mark.}

The alignment with the assessments model can differ with the level of students. Students with higher marks in the previews semester may be more aligned with the assessment components than students with lower marks.

The data were collected from paper questionnaires (Appendix 1 presents the questionnaire). They were distributed by all nine classes, in 2019. It was anonymous and the filling was voluntary. We acquired 232 responses representing a response rate of $89.9 \%$.

The questioner was divided into three part. The first one allows us to characterize the sample and include the age, the gender, the mark obtained in BSPI, and the professional experience. The second part contemplates the components of the collective group assessment such as continuous evaluation of each session that includes the evaluation of multidisciplinary, the evaluation of physical dossiers, the evaluation of the Annual Report and Accounts and the assessment of the writing ability, objectivity, and content structure. The third part of the questioner include the individual components of assessment such as individual evaluation of multidisciplinary contents, oral presentations, ethical behaviours, attendance, and punctuality. For the second and third part of the questioner, we use a Likert Scale between 1 and 5, where 1 is not important and 5 extremely important. To analyse the data, we resort to SPSS.

\section{Findings and Discussion}

\subsection{Resources of Business Simulation Project}

When planning an assessment program one of the approaches to be in consideration has to be the available resources such as physical facilities ${ }^{6}$. 
The course of BSPI and BSPII aims to incorporate new technologies in accounting education and to provide students with several competencies. The course has 30 sessions with three hours each. Their resources are two simulation laboratories each one allows fifteen virtual companies to work simultaneously with two computers (operating in a multi-user company operation), one printer, one scanner, one handheld bar code scanners and one telephone each one, among other material ${ }^{15}$. The course has remote desktop access which allows students to consult the Enterprise Resource Planning and control assessment feedback. The assiduity and punctuality are controlled electronically.

\subsection{Assessment Model}

The BSP evaluation process is based on the execution of tasks and reports, feedback and rectification. The evaluation can be consulted daily by each student through the evaluation result program, which includes the various sessions and the respective evaluation result. The evaluation is divided into a group and individual component.

The assessment components of the group include the evaluation of the multidisciplinary tasks performed in each session. It also includes punctual evaluation of physical files and written assignments such as management reports and a paper about a subject attributed by teachers.

The individual components of evaluation include assiduity and punctuality, ethical behaviour, oral presentation of written papers and two exams.

There is an evaluation summary grid, containing all assessment components. This grid covers all the evaluation tasks such as oral presentation, written tests, execution of tasks, assessment of physical dossiers, punctuality and attendance, ethical behaviour and company management report. This software supports teachers in the sessions and allows transparency in the student's evaluation process. This grid leads to a constructive perception of the evaluation instead of a negative one. It is also a motivating factor since students follow their quantitative grade. The software can be accessed through a remote desktop available for teachers and students. It allows access to all information related to the organization and evaluation of sessions. This link stimulates and enables e-learning, allowing access to all pedagogical, organizational and business contents of the course, in any place at any time.

Table 1 synthesizes the BSP assessment model, identifying the objective, description, assessment method and frequency of assessment.

The evaluation of the multidisciplinary tasks performed in each session is express in table 1 in the objectives of General Knowledge, Organizations and Business Knowledge, and Accounting Knowledge. General Knowledge is based on knowledge about economic, political or social problems. It assessment method is the search and interpretation of newspapers news which occur around five sessions each semester. Organizations and Business Knowledge is based on the ability of students to understand their virtual organization and manage its integrated data information. It assessment method is the management of Enterprise Resource Plan and occur every session. Accounting Knowledge is based on the evaluate of accounting multidisciplinary issues. It assessment method is accounting tasks, documents and reports evaluation in several sessions.

Punctual evaluation of physical files is express in table 1 in the objectives of Organizations and Business Knowledge. It is based on the documental organization every session.

Written assignments such as management reports and a paper about a subject attributed by teachers are express in table 1 in the objectives of Intellectual Skills. It is based on the ability to structure logical and critical thinking, writing ability, objectivity, content structure, and reflection ability. It assessment method is the evaluation of Annual Report and Accounts and a paper, twice per semester. 
The assiduity and punctuality, ethical behaviour, among others are express in table 1 in the objectives of Interpersonal Skills, assessed every session. Oral presentation of written papers is express in table 1 in the objectives of Communication Skills assessed twice per semester. There are also two exams express in table 1 in the objectives of Accounting Knowledge.

The assessment model consider also the student's satisfaction and teacher performance evaluation carried out by the students once per semester. The Accountants Order also audit the course once a year since there is a protocol in which the attendance and approval in the course exemption a professional stage.

Table 1. Business Simulation Project Assessment Model

\begin{tabular}{|c|c|c|c|}
\hline Objective & Description & Assessment Method & $\begin{array}{c}\text { Frequency of } \\
\text { Assessment }\end{array}$ \\
\hline Communication Skills & $\begin{array}{l}\text { Oral communication and } \\
\text { presentation skills }\end{array}$ & $\begin{array}{c}\text { Presentation of } \\
\text { Annual Report and } \\
\text { Accounts and a paper } \\
\text { about attributed } \\
\text { subject }\end{array}$ & $\begin{array}{l}\text { Twice per } \\
\text { semester }\end{array}$ \\
\hline Intellectual Skills & $\begin{array}{c}\text { Ability to structure } \\
\text { logical and critical } \\
\text { thinking, writing ability, } \\
\text { objectivity, content } \\
\text { structure, and reflection } \\
\text { ability }\end{array}$ & $\begin{array}{l}\text { Annual Report and } \\
\text { Accounts and a paper }\end{array}$ & $\begin{array}{l}\text { Twice per } \\
\text { semester }\end{array}$ \\
\hline Interpersonal Skills & $\begin{array}{l}\text { Teamwork, leadership, } \\
\text { work pressure capacity, } \\
\text { ethical behaviours, } \\
\text { attendance, and } \\
\text { punctuality }\end{array}$ & $\begin{array}{l}\text { Task execution and } \\
\text { organization. } \\
\text { Introduction of a large } \\
\text { number of tasks }\end{array}$ & Every session \\
\hline General Knowledge & $\begin{array}{l}\text { Knowledge about } \\
\text { economic, political or } \\
\text { social problems }\end{array}$ & $\begin{array}{c}\text { Search and } \\
\text { interpretation of } \\
\text { newspapers news }\end{array}$ & $\begin{array}{l}\text { Five sessions in } \\
\text { each semester }\end{array}$ \\
\hline $\begin{array}{c}\text { Organizations and Business } \\
\text { Knowledge }\end{array}$ & $\begin{array}{l}\text { Ability to understand } \\
\text { student's virtual } \\
\text { organization, manage its } \\
\text { integrated data } \\
\text { information and } \\
\text { documental organization }\end{array}$ & $\begin{array}{l}\text { Manage Enterprise } \\
\text { Resource Plan. } \\
\text { Physical and } \\
\text { electronic documental } \\
\text { organization }\end{array}$ & Every session \\
\hline Accounting Knowledge & $\begin{array}{l}\text { Evaluate accounting } \\
\text { multidisciplinary issues }\end{array}$ & $\begin{array}{l}\text { Accounting tasks, } \\
\text { documents, and } \\
\text { reports evaluation. } \\
\text { Individual exam }\end{array}$ & $\begin{array}{c}\text { Several Sessions } \\
\text { Twice per } \\
\text { semester } \\
\end{array}$ \\
\hline Students Satisfaction & Level of satisfaction & Students Survey & Once per semester \\
\hline Teacher/Course Evaluation & Teacher Performance & Students Survey & Once per semester \\
\hline $\begin{array}{l}\text { External Evaluation from } \\
\text { Accounting Order }\end{array}$ & $\begin{array}{c}\text { Measure the alignment of } \\
\text { the course curriculum } \\
\text { with the accounting order } \\
\text { agreement }\end{array}$ & $\begin{array}{c}\text { Audits by the } \\
\text { Accounting Order }\end{array}$ & Once a year \\
\hline
\end{tabular}

Source: Adapted from Stivers, Campbell and Hermanson ${ }^{16}$

\subsection{Student's Perception}


We analyse the 232 questionnaires responses using the SPSS. In the school year of $2018 / 2019$, in the course of BSPII, 78,2\% of the students have between 18 and 25 years old. $66,1 \%$ are female and $60,3 \%$ had between $13 / 20$ and $15 / 20$ marks in BSPI. Only $28,8 \%$ have professional experience.

Table 2. Collective Group Assessment

\begin{tabular}{|c|c|c|c|c|}
\hline & Multidisciplinary & $\begin{array}{c}\text { Physical } \\
\text { dossiers }\end{array}$ & $\begin{array}{c}\text { Annual Report } \\
\text { and Accounts }\end{array}$ & $\begin{array}{c}\text { Writing ability, } \\
\text { objectivity and } \\
\text { content structure }\end{array}$ \\
\hline 1.Not important & 0,0 & 1,3 & 0,0 & 1,3 \\
\hline 2. Some importance & 1,7 & 11,5 & 3,0 & 12,8 \\
\hline 3. Important & 15,8 & $\mathbf{4 0 , 6}$ & 16,7 & $\mathbf{4 2 , 7}$ \\
\hline 4. Very important & 40,2 & 32,1 & $\mathbf{4 9 , 6}$ & 32,5 \\
\hline 5. Extremely important & $\mathbf{4 2 , 3}$ & 14,5 & 30,7 & 10,7 \\
\hline
\end{tabular}

Table 2 summarises the collective group assessment.

Regarding the collective group components of evaluation, none was considered not important or of some importance. The most valued component is the evaluation of each session that includes the multidisciplinary, $42 \%$ of the students considered it extremely important. Follow, the evaluation of the Annual Report and Accounts were considered very important for $49,6 \%$ of the students. With a lower degree of importance, there is the evaluation of physical dossiers ( $40.6 \%$ of the students considered it important), and the assessment of the writing ability, objectivity and content structure $(42.7 \%$ of the students considered it important).

Table 3 summarises the individual assessment.

Table 3. Individual Assessment

\begin{tabular}{|c|c|c|c|c|c|}
\hline & $\begin{array}{c}\text { Multidisciplinary } \\
\text { contents }\end{array}$ & $\begin{array}{c}\text { Oral } \\
\text { presentations }\end{array}$ & $\begin{array}{c}\text { Ethical } \\
\text { behaviours }\end{array}$ & Attendance & Punctuality \\
\hline 1.Not important & 4,7 & 1,3 & 1,7 & 0,0 & 0,0 \\
\hline $\begin{array}{c}\text { 2. Some } \\
\text { importance }\end{array}$ & 16,2 & 9,4 & 6,9 & 6,9 & 5,6 \\
\hline 3. Important & $\mathbf{3 3 , 3}$ & 32,5 & 24,9 & 25,3 & 23,2 \\
\hline $\begin{array}{c}4 . \text { Very } \\
\text { important }\end{array}$ & $\mathbf{3 3 , 3}$ & $\mathbf{4 1 , 0}$ & $\mathbf{4 2 , 5}$ & $\mathbf{3 9 , 5}$ & $\mathbf{4 4 , 6}$ \\
\hline $\begin{array}{c}\text { 5. Extremely } \\
\text { important }\end{array}$ & 12,5 & 15,8 & 24,0 & 28,3 & 26,6 \\
\hline
\end{tabular}

Considering the individual components of the assessment, students consider the evaluation exam (multidisciplinary contents) as the least important component (33\% considered important and 33\% very important). This corroborates with studies that consider difficult to motivate students to exam component ${ }^{6}$.

The remain components are perceived to be very important for the students: oral presentations ( $41 \%$ of the students consider very important), ethical behaviours $(42.5 \% \%$ of the students consider very important), attendance $(39.5 \% \%$ of the students consider very important) and punctuality $(44.6 \% \%$ of the students consider very important). The 
importance attribute to punctuality can be related to cultural factors, despite Portuguese don't respect much punctuality students deem it more important than attendance.

The Chi-Square, represented in table 4 and table 5, and Pearson Correlation tests were performed and were inconclusive.

Table 4. Chi-Square Tests - Collective Group Assessment

\begin{tabular}{|c|c|c|c|c|}
\hline & Multidisciplinary & $\begin{array}{c}\text { Physical } \\
\text { dossiers }\end{array}$ & $\begin{array}{c}\text { Annual Report } \\
\text { and Accounts }\end{array}$ & $\begin{array}{c}\text { Writing ability, } \\
\text { objectivity and } \\
\text { content structure }\end{array}$ \\
\hline Chi-Square & $108.256 \mathrm{a}$ & $119.504 \mathrm{~b}$ & $111.470 \mathrm{a}$ & $135.872 \mathrm{~b}$ \\
\hline df & 3 & 4 & 3 & 4 \\
\hline Asymp. Sig. & .000 & .000 & .000 & .000 \\
\hline
\end{tabular}

Table 5. Chi-Square Tests - Individual Assessment

\begin{tabular}{|c|c|c|c|c|c|}
\hline & $\begin{array}{c}\text { Multidisciplinary } \\
\text { contents }\end{array}$ & $\begin{array}{c}\text { Oral } \\
\text { presentations }\end{array}$ & $\begin{array}{c}\text { Ethical } \\
\text { behaviours }\end{array}$ & Attendance & Punctuality \\
\hline Chi-Square & $77.410 \mathrm{~b}$ & $126.128 \mathrm{~b}$ & $122.644 \mathrm{c}$ & $51.240 \mathrm{~d}$ & $71.635 \mathrm{~d}$ \\
\hline df & 4 & 4 & 4 & 3 & 3 \\
\hline Asymp. Sig. & .000 & .000 & .000 & .000 & .000 \\
\hline
\end{tabular}

There is no relationship between the characteristics of the sample and the questions. The perception of the importance of the assessment components is not different from the students with or without professional experience. Also is not different from the best to the worst students, according to the first-semester mark.

Thus we reject both H1 (The students' perception of the several evaluation components differs according to professional experience) and H2 (The students' perception of the various evaluation components differs according to the first-semester mark). There is a homogeneity in the responses. Our conclusion differs from other studies that consider the preferred student's assessment tasks not to be homogeneous ${ }^{9}$.

\section{Conclusions}

We describe the assessment model for a Business Simulation Project of accounting higher education.

This course has incorporated new skills to prepare students for the new challenges in the labour market. These new skills are reflected in new several assessments components that make the course arduous for both students and teachers, therefore some support software was developed.

Most of the students consider important all the components of evaluation: continuous evaluation of each session that includes the evaluation of multidisciplinary, the evaluation of physical dossiers, the evaluation of the Annual Report and Accounts and the assessment of the writing ability, objectivity and content structure, individual evaluation of multidisciplinary contents, oral presentations, ethical behaviours, attendance and punctuality.

There is not a correlation between the importance attributed by students to each assessment components and their mark obtained in the first semester or their professional experience. All components were considered important. The most important component is the evaluation of each session that includes the ability to understand the student's virtual 
organization, manage its integrated data information and accounting multidisciplinary issues. The lesser importance is the evaluation of physical dossiers and individual exam evaluating multidisciplinary contents. Accordingly, students value the importance of new skills such as communications, intellectual, interpersonal, organizations and business knowledge, and accounting knowledge. Consequently, there is an alignment between the student's perception of assessment components and the course assessment model.

We suggestion for further research to inquiry professional accountants in order to perceive the importance attribute to each component or to analyse other higher accounting school's assessment models.

\section{Appendix - Questionnaire}

\section{A - Samples characterization:}

A.1. Age? $18-25$ years

A.2. Gender: $\mathrm{F}$ 26-35 years

more than 35 years

A.3. What grade did you get at the course of Business Simulation Project I? between 10 and 12 values $\square$ between 13 and 15 values $\square$ more than 15 values $\square$ A.4. Did you have or had carried out any professional activity related to the accounting field? Yes No

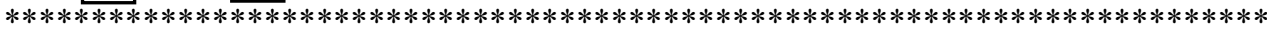
$* * * *$

Taking into account the evaluation components of the Business Simulation Project I and II and considering its relevance for the development of skills for your professional future, what importance do you attach to each component on a scale of 1 to 5 (where 1 is not important) and 5 extremely important).

\section{B - Components of the collective group assessment}

B.1. Continuous assessment of each session, incorporating the assessment of multidisciplinary contents such as balance sheets, accounting entries, VAT declarations, recapitulative statements, bank reconciliation, income tax model, among others.

\begin{tabular}{|c|c|c|c|c|}
\hline $\begin{array}{c}\text { 1.Not } \\
\text { important }\end{array}$ & $\begin{array}{c}\text { 2. Some } \\
\text { importance }\end{array}$ & 3. Important & $\begin{array}{c}\text { 4. Very } \\
\text { important }\end{array}$ & $\begin{array}{c}\text { 5. Extremely } \\
\text { important }\end{array}$ \\
\hline & & & & \\
\hline
\end{tabular}

B.2. Punctual assessment including the evaluation of two physical dossiers: accounting dossier (blue folder) and commercial and company documents dossier (red folder).

\begin{tabular}{|c|c|c|c|c|}
\hline $\begin{array}{c}\text { 1.Not } \\
\text { important }\end{array}$ & $\begin{array}{c}\text { 2. Some } \\
\text { importance }\end{array}$ & 3. Important & $\begin{array}{c}\text { 4. Very } \\
\text { important }\end{array}$ & $\begin{array}{c}\text { 5. Extremely } \\
\text { important }\end{array}$ \\
\hline & & & & \\
\hline
\end{tabular}

B.3. Accountability disclosure including the interim report and the final report.

\begin{tabular}{|c|c|c|c|c|}
\hline $\begin{array}{c}1 . \text { Not } \\
\text { important }\end{array}$ & $\begin{array}{c}\text { 2. Some } \\
\text { importance }\end{array}$ & 3. Important & $\begin{array}{c}\text { 4. Very } \\
\text { important }\end{array}$ & $\begin{array}{c}\text { 5. Extremely } \\
\text { important }\end{array}$ \\
\hline & & & & \\
\hline
\end{tabular}

B.4. Assessment of writing ability, objectivity and structure content, including writing papers on the assigned topic and respective PowerPoint.

\begin{tabular}{|c|c|c|c|c|}
\hline $\begin{array}{c}\text { 1.Not } \\
\text { important }\end{array}$ & $\begin{array}{c}\text { 2. Some } \\
\text { importance }\end{array}$ & 3. Important & $\begin{array}{c}\text { 4. Very } \\
\text { important }\end{array}$ & $\begin{array}{c}\text { 5. Extremely } \\
\text { important }\end{array}$ \\
\hline & & & & \\
\hline
\end{tabular}




\section{C - Components of individual assessment}

C.1. Individual assessment of multidisciplinary content including assessment tests.

\begin{tabular}{|c|c|c|c|c|}
\hline $\begin{array}{c}\text { 1.Not } \\
\text { important }\end{array}$ & $\begin{array}{c}\text { 2. Some } \\
\text { importance }\end{array}$ & 3. Important & $\begin{array}{c}\text { 4. Very } \\
\text { important }\end{array}$ & $\begin{array}{c}\text { 5. Extremely } \\
\text { important }\end{array}$ \\
\hline & & & & \\
\hline
\end{tabular}

C.2. Assessment of oral communication skills including the presentation of the assigned topic and the final report.

\begin{tabular}{|c|c|c|c|c|}
\hline $\begin{array}{c}\text { 1.Not } \\
\text { important }\end{array}$ & $\begin{array}{c}\text { 2. Some } \\
\text { importance }\end{array}$ & 3. Important & $\begin{array}{c}\text { 4. Very } \\
\text { important }\end{array}$ & $\begin{array}{c}\text { 5. Extremely } \\
\text { important }\end{array}$ \\
\hline & & & & \\
\hline
\end{tabular}

C.3. Ethical behaviours assessment including negative behaviours, such as posture in the classroom and relationships with colleagues.

\begin{tabular}{|c|c|c|c|c|}
\hline $\begin{array}{c}\text { 1.Not } \\
\text { important }\end{array}$ & $\begin{array}{c}\text { 2. Some } \\
\text { importance }\end{array}$ & 3. Important & $\begin{array}{c}\text { 4. Very } \\
\text { important }\end{array}$ & $\begin{array}{c}\text { 5. Extremely } \\
\text { important }\end{array}$ \\
\hline & & & & \\
\hline
\end{tabular}

C.4. Attendance assessment.

\begin{tabular}{|c|c|c|c|c|}
\hline $\begin{array}{c}\text { 1.Not } \\
\text { important }\end{array}$ & $\begin{array}{c}\text { 2. Some } \\
\text { importance }\end{array}$ & 3. Important & $\begin{array}{c}\text { 4. Very } \\
\text { important }\end{array}$ & $\begin{array}{c}\text { 5. Extremely } \\
\text { important }\end{array}$ \\
\hline & & & & \\
\hline
\end{tabular}

C.5. Punctuality assessment.

\begin{tabular}{|c|c|c|c|c|}
\hline $\begin{array}{c}\text { 1.Not } \\
\text { important }\end{array}$ & $\begin{array}{c}\text { 2. Some } \\
\text { importance }\end{array}$ & 3. Important & $\begin{array}{c}\text { 4. Very } \\
\text { important }\end{array}$ & $\begin{array}{c}\text { 5. Extremely } \\
\text { important }\end{array}$ \\
\hline & & & & \\
\hline
\end{tabular}

\section{References}

1. Hughes, S. \& Scholtz, F. Increasing the impact of a business simulation: The role of reflection. Int. J. Manag. Educ. 13, 350-361 (2015)

2. Telukdarie, A. \& Munsamy, M. Digitization of Higher Education Institutions. Proc. 2019 IEEE IEEM 716-721 (2019)

3. Mladenovic, R. An investigation into ways of challenging introductory accounting students' negative perceptions of accounting. Account. Educ. 9, 135-155 (2000).

4. Joyce, B., Calhoun, E. \& Hopkins, D. Models of learning e Tools for teaching. (Open University Press, 2009)

5. Boun, D. Reframing assessment as if learning were important. in Rethinking assessment in higher education: Learning for the longer term (Routledge, 2007)

6. Martinson, O. \& Cole, E. Improving accounting education through outcomes assessment. Manag. Account. Q. Winter, 1-6 (2002)

7. Lombardi, A. et al. Higher education and disability: A systematic review of assessment instruments designed for students, faculty, and staff. J. Divers. High. Educ. 11, 34-50 (2018)

8. Fallows, S. Teaching and learning for student skills development. in $A$ handbook for teaching \& learning in higher education (Kogan Page Limited, 2003)

9. Watty, K., Jackson, M. \& Yu, X. Students' approaches to assessment in accounting education: The unique student perspective. Account. Educ. 19, 219-234 (2010)

10. Kerby, D., Romine, J., Kerby, D. \& Romine, J. Develop oral presentation skills through accounting curriculum design and course-embedded assessment. J. Educ. Bus. 85, 172-179 (2009) 
11. Aris, N. A., Baharum, Z., Sanusi, Z. M., Rahman, I. K. A. \& Heang, L. T. Assessment of critical success factors for accounting graduates employability. in BEIAC 2013 2013 IEEE Business Engineering and Industrial Applications Colloquium 526-531 (IEEE, 2013)

12. Maxim, P. S. Quantitative Research Methods in the Social Sciences. (Oxford University Press Inc, 1999)

13. Yin, R. Case Study Research: Design and Methods. (Thousand Oaks: Sage Publications, 1994)

14. Ryan, B., Scapens, R. W. \& Theobald, M. Research Method and Methodology in Finance and Accounting. (Thomson, 2002)

15. Oliveira, H. C., Sá, M., Barros, T. \& Arantes, V. Teaching and learning accounting in an innovative business simulation: portuguese case study. TOJET Turkish Online J. Educ. Technol. Spec. Issue IETC, ITEC, IDEC, ITICAM July, 533-538 (2016)

16. Stivers, B. P., Campbell, J. E. \& Hermanson, H. M. An assessment program for accounting: design, implementation, and reflection. Account. Educ. 15, 553-581 (2000) 